\title{
Glutamine modifies immune responses of mice infected with porcine circovirus type 2
}

\author{
Wenkai Ren ${ }^{1} \dagger$, Yinghui $\mathrm{Li}^{1} \dagger$, Xinglong $\mathrm{Yu}^{2}$, Wei $\mathrm{Luo}^{2}$, Gang Liu ${ }^{1}$, Hua Shao ${ }^{3}$ and Yulong Yin ${ }^{1 *}$ \\ ${ }^{1}$ Key Laboratory of Agro-ecological Processes in Subtropical Region, Research Center for Healthy Breeding of Livestock and \\ Poultry, Hunan Engineering and Research Center of Animal and Poultry Science, Institute of Subtropical Agriculture, \\ Chinese Academy of Sciences, Scientific Observing and Experimental Station of Animal Nutrition and Feed Science in \\ South-Central, Ministry of Agriculture, Changsha City, Furong Road \#644, Hunan 410125, People's Republic of China \\ ${ }^{2}$ College of Veterinarian, Hunan Agricultural University, Changsha, Hunan 410128, People's Republic of China \\ ${ }^{3}$ Ottawa Hospital Research Institute, University of Ottawa, Ottawa, ON, Canada K1Y 4 E9
}

(Submitted 26 July 2012 - Final revision received 12 December 2012 - Accepted 12 December 2012 - First published online 28 January 2013)

Abstract

The present study was conducted to evaluate the immune-enhancing effects of dietary L-glutamine supplementation in porcine circovirus type 2 (PCV2)-infected mice, and to examine the clearance effects of glutamine against PCV2 in experimentally infected mice. A total of sixty Kunming female mice were infected with PCV2 at a dose of 100 TCID $_{50}(50 \%$ tissue culture infection dose) by intraperitoneal injection after 2 weeks of dietary L-glutamine supplementation or L-alanine supplementation (as the control (isonitrogenous) group). The measured variables on 3rd, 5th, 7th, 9th and 11th d post-infection (dpi) included: (1) PCV2 virus loaded in the liver, spleen, heart, lung, kidney, ovary and serum was determined by real-time PCR; (2) IL-2, IL-6, IL-10, interferon (IFN)- $\alpha$, IFN- $\gamma$ and C-reactive protein levels in serum were measured by ELISA; (3) serum total superoxide dismutase activity was measured spectrophotometrically at $550 \mathrm{~nm}$ absorbance. Dietary L-glutamine supplementation significantly increased serum IL-2 levels on the 3 rd $(P<0 \cdot 01)$, 5th $(P<0 \cdot 01)$, 7th $(P<0 \cdot 05)$ and 9 th $\mathrm{dpi}$, significantly $(P<0.05)$ increased serum IL-6 levels on 3rd dpi, significantly $(P<0.05)$ increased serum IFN- $\gamma$ levels on the 9th and 11 th dpi and significantly decreased $(P<0 \cdot 01)$ serum IL-10 levels on the 9th and 11th dpi, compared with those in the control group. Meanwhile, the PCV2 virus genome was detected sporadically throughout the experimental period in both groups. Taken together, the present results suggest that dietary L-glutamine supplementation enhances immune function in PCV2-infected mice.

Key words: L-Glutamine: Porcine circovirus type 2: Amino acids: Antioxidation: Immune function

The Circoviridae family are small, icosahedral, non-enveloped viruses with single-stranded, circular DNA genomes. There are two genera (Gyrovirus and Circovirus) in the family of Circoviridae that are characterised according to their genome sizes and differences in genome organisation. Porcine circovirus types 1 and 2 (PCV1 and PCV2, respectively) belong to the Circovirus genus ${ }^{(1-3)}$. PCV1 is non-pathogenic and has not been reported to associate with naturally occurring diseases, while PCV2 has been suggested as the essential pathogen for the post-weaning multi-systemic wasting syndrome (PMWS $^{(4,5)}$ and porcine circovirus-associated diseases or porcine circovirus diseases ${ }^{(6,7)}$. The compelling pathological finding is that PCV2 infection damages macrophages, antigen-presenting cells and other immune-related cells ${ }^{(8)}$ So the PMWS is considered as an immunosuppressive disease, and the interaction between PCV2 and the immune system is suggested as a determining factor in the pathogenesis of the PMWS ${ }^{(9)}$.

Glutamine, an immunonutrient and modulator, plays a role in the interaction between the carbon metabolism of carbohydrates and proteins, and has also been found to play an important role in the development of fibroblasts, lymphocytes and enterocytes ${ }^{(10-12)}$. A large body of evidence shows that glutamine has various beneficial effects on immune and intestinal functions. For example, it was found that glutamine functions as a major energy substrate for cells of the immune

\footnotetext{
Abbreviations: CRP, C-reactive protein; dpi, days post-infection; IFN, interferon; PCV, porcine circovirus; PMWS, post-weaning multi-systemic wasting syndrome; SOD, superoxide dismutase; TCID $_{50}, 50 \%$ tissue culture infection dose.
}

*Corresponding author: Y. Yin, email yinyulong@isa.ac.cn

† Both authors contributed equally to this work. 
system $^{(13-15)}$ and that the provision of glutamine enhances the immunity of the host ${ }^{(16-19)}$. Moreover, research demonstrated that the ability of lymphocytes to respond to mitogenic stimulation is impaired after failure to supplement culture media with glutamine. Further studies indicated that glutamine is required in terminally differentiated macrophages for the synthesis of mRNA for producing secretory proteins in immune challenge during pinocytosis or phagocytosis ${ }^{(20)}$. Other compelling evidence for the physiological functions of glutamine is its relationship with intracellular redox status and oxidative stress. Collectively, accumulating evidence suggests that glutamine plays important roles in promoting immune functions and preventing diseases, especially subclinical and immunosuppressive diseases.

The aims of the present study were to evaluate the immuneenhancing effects of dietary L-glutamine supplementation in PCV2-infected mice, and to investigate the potential of clearing PCV2 in experimentally infected mice.

\section{Materials and methods}

\section{Animals and feeding}

A total of sixty Kunming female mice (body weight 18-22 g) were obtained from the Laboratory Animal Center of Central South University, Hunan, China ${ }^{(21)}$. Mice were randomly assigned to two treatment groups after $3 \mathrm{~d}$ of adaptive feeding: glutamine group (1.0\% glutamine + basal diet, $n$ 30) and control group (1.22\% alanine + basal diet, $n$ 30). Glutamine and alanine were purchased from Beijing Chemclin Biotech ${ }^{(22)}$. Amino acid content in the basal diet was measured using an Automatic Amino Acid Analyzer (L-8900; Hitachi) ${ }^{(23)}$. This basal diet contained $1.94 \%$ L-glutamate, $1.80 \%$ L-glutamine and $0.91 \% \mathrm{~L}$-alanine. Mice were housed in an environmentally controlled pathogen-free condition. All animals were fed ad libitum. The study was carried out in full compliance with the guidelines for animal welfare and was approved by the Animal Care and Use Committee of the Chinese Academy of Sciences (registry no. 011063506) ${ }^{(24)}$.

\section{Preparation of porcine circovirus type 2 stock}

A PCV2 infectious clone constructed by self-ligation of the PCV2 genome via the SacII enzyme site was used to generate the virus stock pools required for experimental infections. Briefly, the continuous porcine kidney cell line PK-15 (gift from Professor Yang, China Agricultural University) ${ }^{(25)}$, free of PCV1 and PCV2, was cultured in Roswell Park Memorial Institute (RPMI)-1640 medium supplemented with 6\% (v/v) fetal calf serum. The cell monolayer was dispersed by treating the cells with trypsin-EDTA, and suspended in RPMI-1640 medium supplemented with $6 \%(\mathrm{v} / \mathrm{v})$ fetal calf serum while cells were infected with the PCV2 infectious clone. After $72 \mathrm{~h}$ of incubation, the infected cells were frozen and thawed thrice, and the cell mixture was tested by PCR before storing them at $-20^{\circ} \mathrm{C}$. PCV2 stocks were titrated on PK-15 cells (gift from Professor Yang, China Agricultural University) ${ }^{(25)}$.

\section{Experimental design}

Mice were infected with PCV2 at a dose of 100 TCID $_{50}(50 \%$ tissue culture infection dose) by intraperitoneal injection after 2 weeks of feeding L-glutamine. On 3rd, 5th, 7th, 9th and 11thd post-infection (dpi), six mice from each group were killed to collect liver, spleen, heart, lung, kidney and ovary, and serum was prepared from blood samples collected from the orbital vein. All the samples were stored at $-80^{\circ} \mathrm{C}^{(26,27)}$.

\section{Serum cytokine detection}

Serum levels of IL-2, IL-6, IL-10, interferon (IFN)- $\alpha$, IFN- $\gamma$ and C-reactive protein (CRP) were measured using ELISA kits in accordance with the manufacturer's instructions (Cusabio Biotech Company Limited) ${ }^{(28,29)}$. Supplied diluent buffer in the kits was used to dilute standards and serum samples. Next, $100 \mu \mathrm{l}$ of the sample or standard in duplicate were added to the wells of a microtitre plate pre-coated with antibody. Diluent buffer was used as a negative control. The plate was incubated for $2 \mathrm{~h}$ at $37^{\circ} \mathrm{C}$. After incubation, $100 \mu \mathrm{l}$ of biotin antibody were added to each well after removing the liquid from each well and incubated for $1 \mathrm{~h}$ at $37^{\circ} \mathrm{C}$. The wells were washed thrice with $200 \mu \mathrm{l}$ volumes of wash buffer. Next, $100 \mu \mathrm{l}$ horseradish peroxidase-avidin were added to each well for $1 \mathrm{~h}$ at $37^{\circ} \mathrm{C}^{(30)}$. After a final wash, $90 \mu \mathrm{l}$ of the supplied chromogen were added and incubated for $30 \mathrm{~min}$ in the dark at $37^{\circ} \mathrm{C}$. The reaction was stopped with $50 \mu \mathrm{l}$ of the supplied stop solution and absorbance was measured at $450 \mathrm{~nm}$ with a spectrophotometer.

\section{DNA extraction and porcine circovirus type 2 quantitative $P C R$}

DNA from samples (liver, $10 \mathrm{mg}$; spleen, $5 \mathrm{mg}$; heart, $10 \mathrm{mg}$; lung, $10 \mathrm{mg}$; kidney, $10 \mathrm{mg}$; ovary, $10 \mathrm{mg}$ ) was extracted using Tissue Genomic DNA Extraction Kits (Betimes Biotechnology Company, Limited) according to the manufacturer's instructions. DNA from the samples was eluted with $80 \mu \mathrm{l}$ of elution buffer and stored at $-20^{\circ} \mathrm{C}$. PCV2 in the extracted DNA was quantified using real-time PCR. Before quantification of the PCV2 genome in the collected samples, a PCV2 real-time PCR standard was established. Briefly, the PCV2 genome was cloned in the $\mathrm{pMD}^{\circledR} 18$ - $\mathrm{T}$ Vector (TaKaRa) after PCR amplification with primers - forward 5'-CCGCGGGCTGGCTGAACTTTTGAAAG-3 $3^{\prime}$ and reverse $5^{\prime}$-CCGCGGAAATTTCTGACAAACGTTAC-3' (GenBank accession no. EU095020) and transformed in TOP10 competent cells (Invitrogen). The plasmid was prepared using a PureLinkTM HiPure Plasmid Midiprep Kit (Invitrogen). The PCV2 plasmid was mixed with mouse DNA extracted from a PCV2 PCR-negative blood sample. Dilutions (10-fold) of this mixture (from $10^{11}$ to $10^{2}$ PCV2 copy numbers/ $\mu$ l) were used as a standard for PCV2 quantification. The PCR was performed using a SYBR Green detection kit (Takara), containing $\mathrm{MgCl}_{2}$, deoxyribonucleoside triphosphate (dNTP) and HotStar Taq polymerase. Then, $1 \mu \mathrm{l}$ of the template solution was added to a total volume of 
$10 \mu \mathrm{l}$ containing $5 \mu \mathrm{l}$ SYBR Green mix (Takara) and $0 \cdot 2 \mu \mathrm{l}$ each of the forward and reverse primers $(10 \mu \mathrm{m})$. The PCR was performed under the following conditions: (1) pre-denaturation $\left(30 \mathrm{~s}\right.$ at $\left.95^{\circ} \mathrm{C}\right)$; (2) amplification and quantification, repeated forty cycles $\left(5 \mathrm{~s}\right.$ at $95^{\circ} \mathrm{C}, 34 \mathrm{~s}$ at $\left.60^{\circ} \mathrm{C}\right)$; (3) melting $\left(60-99^{\circ} \mathrm{C}\right.$ at a heating rate of $\left.0 \cdot 1^{\circ} \mathrm{C} / \mathrm{s}\right)^{(31)}$.

\section{Total superoxide dismutase activity detection}

Total superoxide dismutase (SOD) activity in serum was determined using spectrophotometric kits at $550 \mathrm{~nm}$ (Nanjing Jiancheng Biotechnology Institute) according to the manufacturer's instructions. The results were expressed as units/ml serum.

\section{Statistical analysis}

All statistical analyses were performed using SPSS 16.0 software (SPSS, Inc.). Group comparisons were performed using Student's $t$ test, and data from different time points within the glutamine group were performed using the StudentNewman-Keuls method. Data of the detection rate in each tissue were analysed by Fisher's exact test. Differences were considered significant at $P<0 \cdot 05$. Data are expressed as means with their standard errors of the mean ${ }^{(32)}$.

\section{Results}

In the present study, a series of cytokines related to the pathogenesis of the PMWS were measured to evaluate the immuneenhancing effects of glutamine supplementation. Meanwhile, the total SOD activity in serum was also analysed to profile the redox status in the body. The results showed that dietary L-glutamine supplementation significantly increased serum IL-2 levels on the 3 rd $(P<0.01)$, 5th $(P<0.01)$, 7th $(P<0.05)$ and 9th dpi $(P<0.05)$, while IL-2 levels on the 7 th dpi were much higher $(P<0.05)$ than those on the 5th and 11th dpi in the glutamine group (Fig. 1). Serum IL-6 levels in the glutamine group were also significantly $(P<0 \cdot 05)$ higher than those in the control group on the 3rd dpi, while IL-6 levels on the

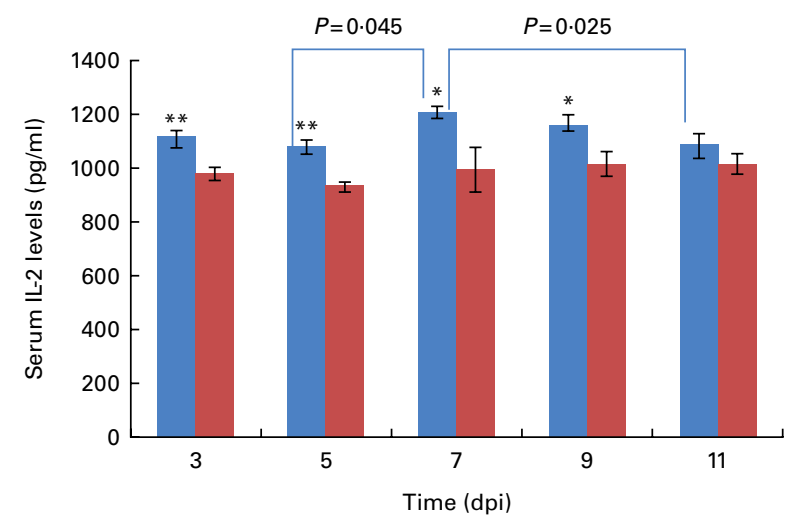

Fig. 1. Serum IL-2 levels in the glutamine $(\square)$ and alanine ( $\square$ ) groups. Mice in the glutamine group were fed with the $1.0 \%$ glutamine + basal diet, while mice in the alanine group were fed with the $1.22 \%$ alanine + basal diet. dpi, Days post-infection. ${ }^{\star} P<0.05 ;{ }^{\star \star} P<0.01$. A colour version of this figure can be found online at journals.cambridge.org/bjn

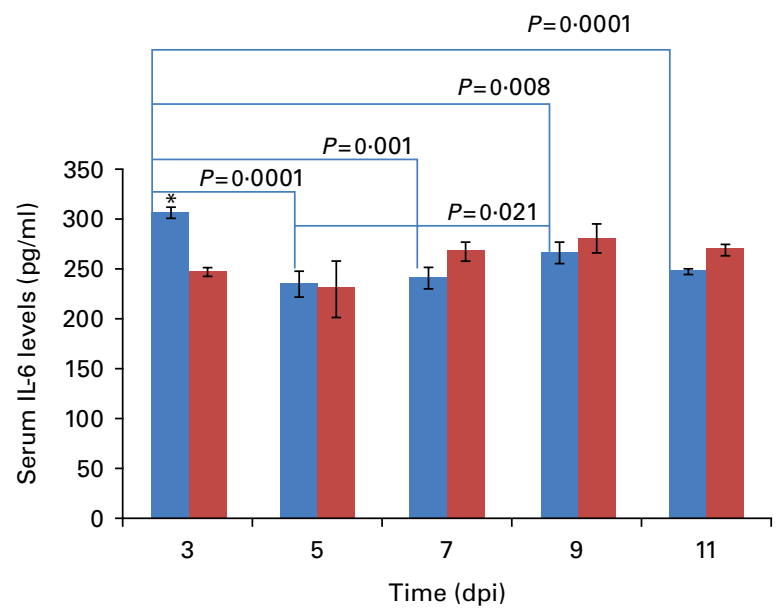

Fig. 2. Serum IL-6 levels in the glutamine $(\square)$ and alanine $(\square)$ groups. Mice in the glutamine group were fed with the $1.0 \%$ glutamine + basal diet, while mice in the alanine group were fed with the $1.22 \%$ alanine + basal diet. dpi, Days post-infection. ${ }^{\star} P<0.05$. A colour version of this figure can be found online at journals.cambridge.org/bjn

3rd dpi were much higher $(P<0 \cdot 01)$ than those on the 5 th, 7th, 9th and 11th dpi in the glutamine group (Fig. 2). Furthermore, dietary glutamine supplementation significantly increased $(P<0.05)$ serum IFN- $\gamma$ levels on the 9th and 11th dpi, while IFN- $\gamma$ levels on the 9th and 11th dpi were much higher than those on the $3 \mathrm{rd}$, 5th and 7 th dpi in the glutamine group (Fig. 5). Serum IL-10 levels in the alanine group were much higher than those in the glutamine group on the 9th and 11th dpi. IL-10 levels on the 3rd dpi were significantly higher $(P<0.05)$ than those on the 7 th, 9th and 11th dpi in the gluatamine group (Fig. 3). No significant difference was observed for serum IFN- $\alpha$ levels (Fig. 4), CRP levels (Fig. 6) and total-SOD activity (Fig. 7) between the glutamine and alanine groups, while, in the glutamine group, IFN- $\alpha$ levels significantly $(P<0.05)$ decreased on the 5th dpi when compared with those on the 3rd, 9th and 11th dpi (Fig. 4). Meanwhile, CRP levels significantly $(P<0 \cdot 01)$ increased on the 9 th and 11th dpi compared with those on the 3rd and 5th dpi (Fig. 6).

In the present study, to explore the clearance effects of glutamine against PCV2 in the mouse model, PCR and quantitative PCR were used to detect the PCV2 virus load in liver, spleen, heart, lung, kidney and ovary tissue, and serum on the $3 \mathrm{rd}$, 5th, 7th, 9th and 11th dpi. For this purpose, first, PCV2 real-time PCR standard and the DNA template from each sample were prepared. The PCR was then used to screen the template, which showed that most of the samples were negative. Furthermore, using quantitative real-time PCR, we detected the PCV2 virus genome sporadically in liver, spleen, heart, lung, kidney and ovary tissue, and serum on the $3 \mathrm{rd}$, 5th, 7th, 9th and 11th dpi (Table 1 shows the data from the 5 th, 7 th, 9 th and 11 th dpi).

\section{Discussion}

Glutamine is generally considered as a non-essential amino acid, which is synthesised mainly in the muscle from nonessential amino acids and glucose. However, in a situation 


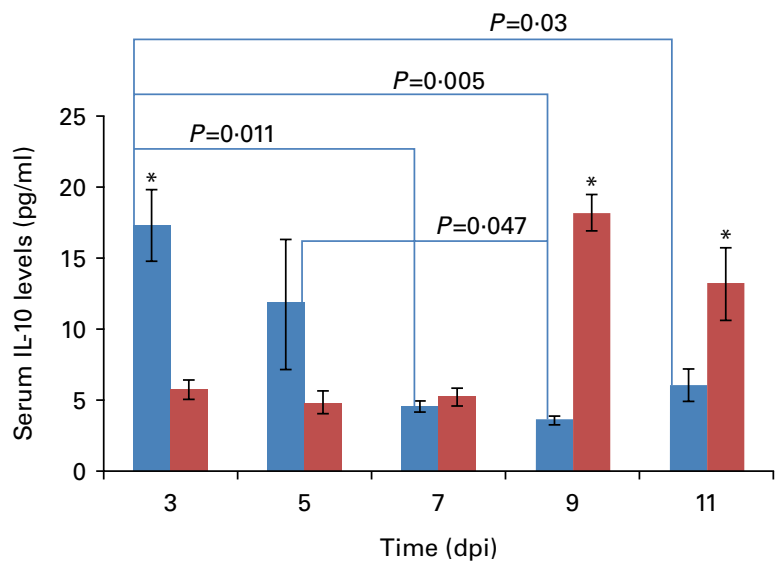

Fig. 3. Serum IL-10 levels in the glutamine $(\square)$ and alanine $(\square)$ groups. Mice in the glutamine group were fed with the $1.0 \%$ glutamine + basal diet, while mice in the alanine group were fed with the $1.22 \%$ alanine + basal diet. dpi, Days post-infection. ${ }^{*} P<0.01$. A colour version of this figure can be found online at journals.cambridge.org/bjn

of abnormal muscle protein metabolism, the production of endogenous glutamine is probably impaired and becomes a conditionally essential amino acid in disease conditions such as major trauma, major surgery, sepsis, bone marrow transplantation, intense chemotherapy and radiotherapy ${ }^{(12)}$. So we hypothesised that glutamine content in the feed is not enough for the pig suffering from a viral or bacterial infection similar to arginine ${ }^{(33,34)}$, and dietary L-glutamine supplementation performs various beneficial effects on a PCV2-infected mouse model.

The mechanisms of immunosuppression in PCV2 infection are described by lymphocyte depletion, interfering with antigen presentation and the induction of apoptosis in the immune system for its main target cells that are considered to be monocyte/macrophage lineage cells and other antigenpresenting cells ${ }^{(35)}$. Meanwhile, recent studies have suggested that lymphocyte-like cells may be important cell populations that support early PCV2 replication, whereas monocytes may be the site for PCV2 persistence in the infected host ${ }^{(36)}$. So PCV2 infection could down-regulate IL-2 expression, but up-regulate other pro-inflammatory mediators such IL-8, IL-1 and IL- $6^{(37)}$. Other compelling research has indicated that PCV2 infection could impair natural IFN-producing cell activity $^{(38,39)}$. Thus, PCV2 infection may decrease IFN- $\alpha$ levels. The number of IL-10-producing cells is higher in all PMWS animals compared with control pigs not infected with PCV2 ${ }^{(40)}$. This could explain why IL-10 is increased in PCV2 infection.

IL-2 is secreted by activated T lymphocytes, especially by activated $\mathrm{CD}^{+}{ }^{+}$T-helper cells and $\mathrm{CD}^{+}{ }^{\mathrm{T}}$-helper cells ${ }^{(41)}$, and named $\mathrm{T}$-cell growth factor as it stimulates $\mathrm{T}$ cell proliferation and differentiation ${ }^{(42,43)}$. IL-2 could promote the activity of immune cells to kill cancer cells, abnormal cells infected by virus and bacteria ${ }^{(44,45)}$. In the present study, dietary L-glutamine supplementation significantly increased serum IL-2 levels on the $3 \mathrm{rd}$, 5th, 7 th and 11 th dpi. IL-6 plays a very complex role in biological events, including immune responses, haematopoiesis, and regulation of the endocrine and nervous systems ${ }^{(46,47)}$.
Here, we found that serum IL-6 levels in the glutamine group was significantly higher than those in the control group on the 3 rd dpi. The prime function of IL-10 is to inhibit many functions of natural killer cells, $\mathrm{T}$ cells, and macrophage and dendritic cells, and to reduce the production of inflammatory cytokines $^{(48,49)}$. There is an indication of a transient correlation between IL-10 levels and the viral load of PCV2 in pigs ${ }^{(50)}$. In the present study, serum IL-10 levels were significantly decreased $(P<0.01)$ in the glutamine group on the 9th and 11 th dpi. IFN- $\gamma$ is a multifunctional protein first observed as an anti-viral activity in cultures of Sindbis virus-infected human leucocytes stimulated by phytohaemagglutinin (PHA). Later work indicated that it induces anti-viral, anti-proliferative and immunomodulatory effects on target cells ${ }^{(51)}$. A significantly higher serum IFN- $\gamma$ level was observed in the glutamine group on the 9th and 11th dpi. IFN- $\alpha$ is a member of the type I IFN family, which is active as an anti-viral and immunomodulatory cytokine. CRP is a product of hepatocytes as a non-specific response to tissue damage. However, no significant difference in serum IFN- $\alpha$ and CRP levels was found between the glutamine and control groups. SOD is an important antioxidant enzyme that could increase the clearance of the superoxide radical. It has already been reported that administration of SOD is effective in decreasing tissue inflammation and injury in experimental models of ischaemia and reperfusion, chronic gut inflammation, arthritis and immune complex-induced pulmonary disease ${ }^{(52)}$. Evidence indicates that glutamine supplementation increases antioxidant defence ability as glutamine up-regulates the synthesis of glutathione and antioxidative gene expression ${ }^{(53,54)}$. Unfortunately, no significant difference was observed for totalSOD activity between the glutamine and alanine groups.

Collectively, dietary $1.0 \% \mathrm{~L}$-glutamine supplementation had a beneficial effect on the cytokine profile in the PCV2-infected mouse model. Cytokines are a large family of proteins and important players in innate and adaptive immune systems, which are produced by leucocytes and other cells. Glutamine

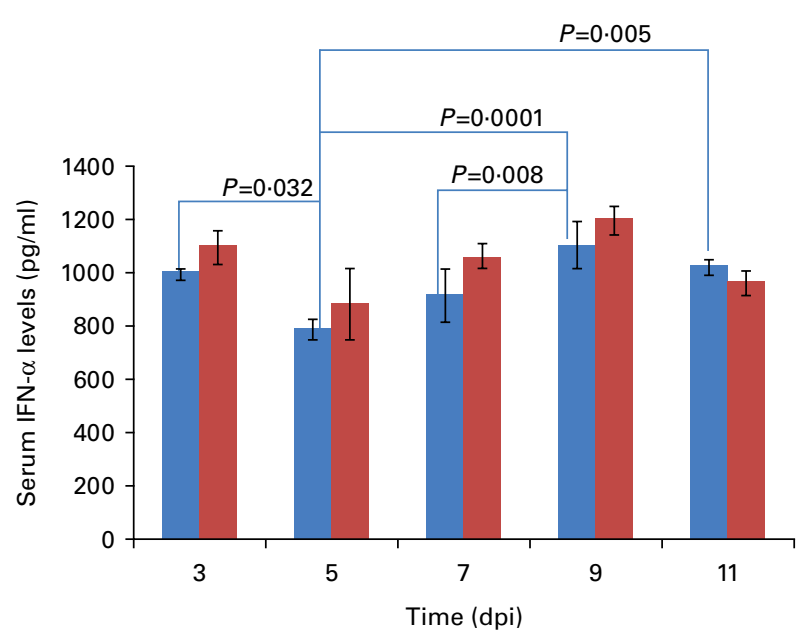

Fig. 4. Serum interferon (IFN)- $\alpha$ levels in the glutamine ( $\square$ ) and alanine ( $\square$ ) groups. Mice in the glutamine group were fed with the $1.0 \%$ glutamine + basal diet, while mice in the alanine group were fed with the $1.22 \%$ alanine + basal diet. dpi, Days post-infection. A colour version of this figure can be found online at journals.cambridge.org/bjn 


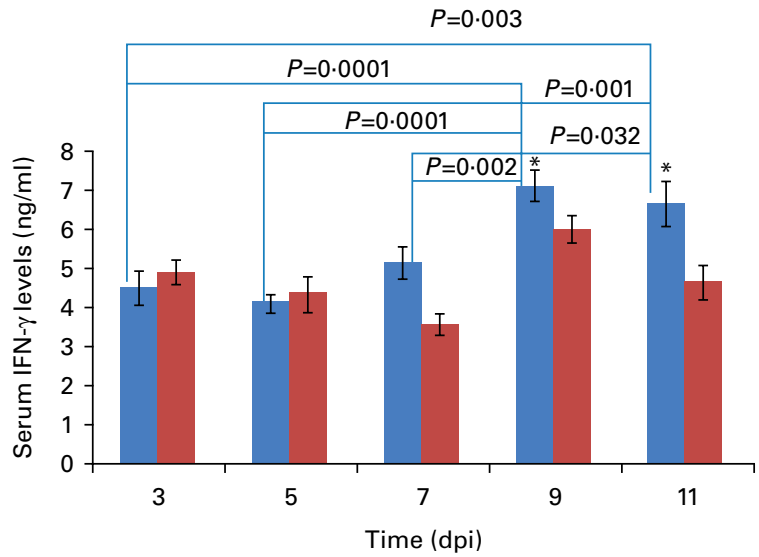

Fig. 5. Serum interferon (IFN)- $\gamma$ levels in the glutamine ( $\square$ ) and alanine ( $\square$ ) groups. Mice in the glutamine group were fed with the $1.0 \%$ glutamine + basal diet, while mice in the alanine group were fed with the $1.22 \%$ alanine + basal diet. dpi, Days post-infection. ${ }^{*} P<0.05$. A colour version of this figure can be found online at journals.cambridge.org/bjn

displays a number of pharmacological actions and is a fuel for all rapidly differentiated and/or activated cells, including phagocytes, lymphocytes and other immune-related cells ${ }^{(55,56)}$. Thus, it is not unexpected that serum cytokine levels would not be ameliorated after glutamine supplementation. In fact, another interesting experiment showed that maximal IL-1 and TNF- $\alpha$ production by cultured murine macrophages, and maximal production of IL- 6 and IL- 8 by cultured human monocytes require a sufficient supply of glutamine ${ }^{(57)}$. However, the other mechanisms by which glutamine regulates the cytokine profile need further study.

In the present study, to explore the clearance effects of glutamine against PCV2 in a mouse model, PCR and quantitative PCR were applied to detect the PCV2 virus load in liver, spleen, heart, lung, kidney and ovary tissue, and serum on the 3rd, 5th, 7th, 9th and 11th dpi. Unfortunately, the PCV2 virus genome was detected sporadically. In fact, this irregularity also existed in other experiments using PCV2 experimentally infected mice ${ }^{(58)}$. Although there has been a promising progress in PCV2 research, little information is known about PCV2 performance in species other than swine. There are only a few studies about PCV2 performance in mice, but their results are mixed. Kiupel et al. ${ }^{(59,60)}$ showed that PCV2 replicates in 8-week-old BALB/C mice inoculated with PCV2, and PCV2 is detected by in situ hybridisation and PCR in mice on 7, 14, 28 and $42 \mathrm{dpi}$. In agreement with Kiupel, Li et al. ${ }^{(61)}$ also found that PCV2 replication, seroconversion and microscopic lesions are found in inoculated Kunming mice, and that Kunming mice could be infected by the PCV2 virus and used as a PCV2-infected experimental model. However, Quintana et al. ${ }^{(62)}$ indicated that porcine circoviruses do not cause any disease or microscopic lesions in inoculated mice during the experimental period, and intraperitoneally inoculated mice might have harboured PCV2 in the circulation without the evidence of viral replication. Meanwhile, Opriessnig et al. ${ }^{(63)}$ also reported that the PCV2 DNA is detected by PCR in 93\% (100/108) of tissues and $42.6 \%$ ( 46 out of 108) of serum samples from PCV2-inoculated mice from days 12 to 37 and the mouse model probably has

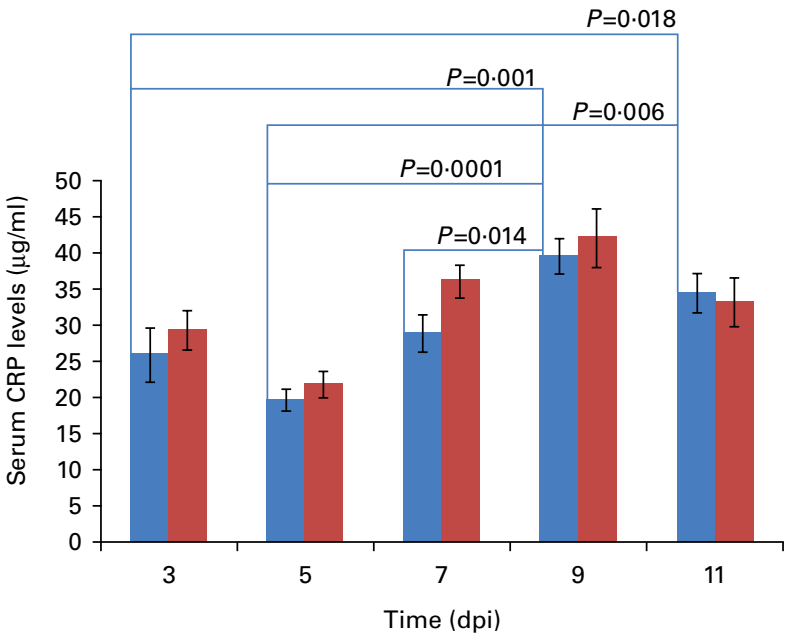

Fig. 6. Serum C-reactive protein (CRP) levels in the glutamine ( $\square$ ) and alanine $(\square)$ groups. Mice in the glutamine group were fed with the $1.0 \%$ glutamine + basal diet, while mice in the alanine group were fed with the $1.22 \%$ alanine + basal diet. dpi, Days post-infection. A colour version of this figure can be found online at journals.cambridge.org/bjn

limited utility to advance the understanding of the pathogenesis of PCV2-associated lesions, but mice could be potentially important in the epidemiology of PCV2. The main reason is that the virus stock (i.e. passage, origin and dose) used in these studies differed.

The speculative reasons that the PCV2 virus genome was detected sporadically are as follows. (1) Although the virus stock is different, the dose that we used was not enough. Li et $a l .{ }^{(61)}$ inoculated mice orally and intramuscularly with $0 \cdot 1 \mathrm{ml} \mathrm{PCV} 2\left(106 \cdot 2 \mathrm{TCID}_{50} / \mathrm{ml}\right)$. (2) The time limited our observation. Bolin et al. ${ }^{(64)}$ reported that PCV2 DNA could be detected by PCR from brain, lymphoid tissue, bone marrow, kidney, ileum, liver, heart, lung, spleen, thymus, tonsil and pancreas from 20 to 28 dpi in caesarean-derived, colostrum-deprived pigs inoculated with PCV2 intranasally and subcutaneously. In fact, we found that PCV2 DNA could be detected in serum from $14 \mathrm{dpi}$ in our other studies when we incubated mice with 100 TCID $_{50}$. (3) Amino acid supplementation in the present

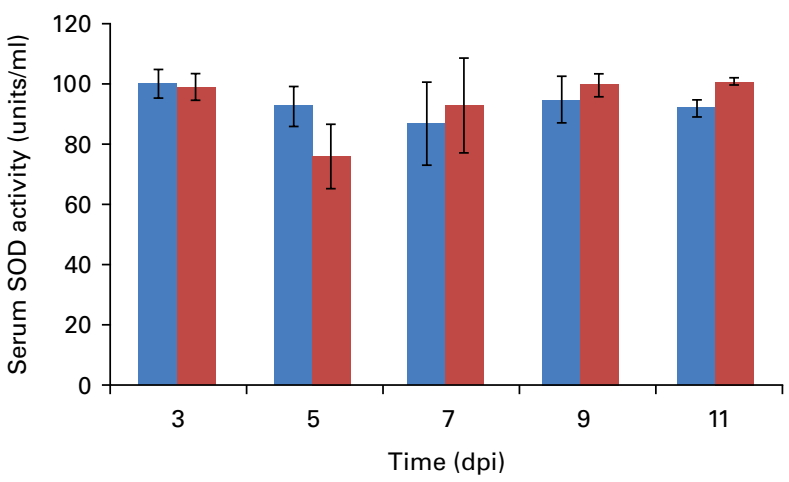

Fig. 7. Serum total-superoxide dismutase (SOD) activity in the glutamine ( and alanine ( $\square$ ) groups. Mice in the glutamine group were fed with the $1.0 \%$ glutamine + basal diet, while mice in the alanine group were fed with the $1.22 \%$ alanine + basal diet. dpi, Days post-infection. A colour version of this figure can be found online at journals.cambridge.org/bjn 
Table 1. Porcine circovirus type 2 (PCV2) virus load in the liver, spleen, heart, lung, kidney and ovary tissue, and serum of control and glutamine-supplemented mice (Mean values with their standard errors for PCV2 $\log _{10}$ genomic copies/g sample or $\mathrm{ml}$ serum)

\begin{tabular}{|c|c|c|c|c|c|c|c|c|c|c|c|c|}
\hline & \multicolumn{3}{|c|}{ 5th dpi } & \multicolumn{3}{|c|}{ 7th dpi } & \multicolumn{3}{|c|}{ 9th dpi } & \multicolumn{3}{|c|}{ 11th dpi } \\
\hline & $\begin{array}{l}\text { Number of positive } \\
\text { mice/number } \\
\text { of tested mice }\end{array}$ & Mean & SEM & $\begin{array}{l}\text { Number of positive } \\
\text { mice/number } \\
\text { of tested mice }\end{array}$ & Mean & SEM & $\begin{array}{l}\text { Number of positive } \\
\text { mice/number } \\
\text { of tested mice }\end{array}$ & Mean & SEM & $\begin{array}{l}\text { Number of positive } \\
\text { mice/number } \\
\text { of tested mice }\end{array}$ & Mean & SEM \\
\hline \multicolumn{13}{|l|}{ Liver } \\
\hline $1.0 \%$ Gln & $0 / 6$ & 0.00 & 0.00 & $0 / 6$ & 0.00 & 0.00 & $0 / 6$ & 0.00 & 0.00 & $1 / 6$ & 1.07 & 0.00 \\
\hline $1.22 \%$ Ala & $0 / 6$ & 0.00 & 0.00 & $1 / 6$ & $2 \cdot 31$ & 0.00 & $0 / 6$ & 0.00 & 0.00 & $0 / 6$ & 0.00 & 0.00 \\
\hline \multicolumn{13}{|l|}{ Spleen } \\
\hline $1.0 \% \mathrm{Gln}$ & $0 / 6$ & 0.00 & 0.00 & $1 / 6$ & 2.48 & 0.00 & $2 / 6$ & 2.79 & 0.00 & $0 / 6$ & 0.00 & 0.00 \\
\hline $1.22 \%$ Ala & $0 / 6$ & 0.00 & 0.00 & $0 / 6$ & 0.00 & 0.00 & $1 / 6$ & 1.74 & 0.00 & $1 / 6$ & 3.06 & 0.00 \\
\hline \multicolumn{13}{|l|}{ Heart } \\
\hline $1.0 \% \mathrm{Gln}$ & $0 / 6$ & 0.00 & 0.00 & $0 / 6$ & 0.00 & 0.00 & $0 / 6$ & 0.00 & 0.00 & $0 / 6$ & 0.00 & 0.00 \\
\hline $1.22 \%$ Ala & $0 / 6$ & 0.00 & 0.00 & $0 / 6$ & 0.00 & 0.00 & $0 / 6$ & 0.00 & 0.00 & $0 / 6$ & 0.00 & 0.00 \\
\hline \multicolumn{13}{|l|}{ Lung } \\
\hline $1.0 \% \mathrm{Gln}$ & $0 / 6$ & 0.00 & 0.00 & $1 / 6$ & 1.95 & 0.00 & $0 / 6$ & 0.00 & 0.00 & $2 / 6$ & 3.41 & 0.00 \\
\hline $1.22 \%$ Ala & $0 / 6$ & 0.00 & 0.00 & $2 / 6$ & 1.83 & 0.00 & $1 / 6$ & 0.00 & 0.00 & $2 / 6$ & 3.62 & 0.00 \\
\hline \multicolumn{13}{|l|}{ Kidney } \\
\hline $1.0 \% \mathrm{Gln}$ & $0 / 6$ & 0.00 & 0.00 & $0 / 6$ & 0.00 & 0.00 & $0 / 6$ & 0.00 & 0.00 & $0 / 6$ & 0.00 & 0.00 \\
\hline $1.22 \%$ Ala & $0 / 6$ & 0.00 & 0.00 & $1 / 6$ & 2.41 & 0.00 & $0 / 6$ & 0.00 & 0.00 & $2 / 6$ & 4.02 & 0.00 \\
\hline \multicolumn{13}{|l|}{ Ovary } \\
\hline $1.0 \% \mathrm{Gln}$ & $0 / 6$ & 0.00 & 0.00 & $0 / 6$ & 0.00 & 0.00 & $1 / 6$ & 3.59 & 0.00 & $0 / 6$ & 0.00 & 0.00 \\
\hline $1.22 \%$ Ala & $0 / 6$ & 0.00 & 0.00 & $0 / 6$ & 0.00 & 0.00 & $0 / 6$ & 0.00 & 0.00 & $0 / 6$ & 0.00 & 0.00 \\
\hline \multicolumn{13}{|l|}{ Serum } \\
\hline $1.0 \% \mathrm{Gln}$ & $2 / 6$ & 2.94 & 0.00 & $0 / 6$ & 0.00 & 0.00 & $1 / 6$ & $3 \cdot 71$ & 0.00 & $0 / 6$ & 0.00 & 0.00 \\
\hline $1.22 \%$ Ala & $1 / 6$ & 2.08 & 0.00 & $0 / 6$ & 0.00 & 0.00 & $0 / 6$ & 0.00 & 0.00 & $2 / 6$ & 6.08 & 0.00 \\
\hline
\end{tabular}

dpi, Days post-infection; $1.0 \%$ Gln, $1.0 \%$ glutamine + gestation diet; $1.22 \%$ Ala, $1.22 \%$ alanine + gestation diet. 
study could be sufficient to clear the virus. Questions about this phenomenon also existing in the control group of the present study will be generated. In the present study, alanine was chosen as a $\mathrm{N}$ control in such a model; however, research has found that alanine also had some effect on immune function ${ }^{(65)}$. Meanwhile, alanine also plays a role in the inhibition of pyruvate kinase and hepatic autophagy, gluconeogenesis, transamination and the glucose-alanine cycle ${ }^{(66,67)}$.

In conclusion, this is the first report that dietary L-glutamine supplementation enhances immune function in PCV2-infected mice, and may clear PCV2 in experimentally infected mice; however, its effect on swine and its mechanism need further investigation.

\section{Acknowledgements}

The present study was jointly supported by the National Basic Research Project (2012CB124704 and 2013CB127301), the NSFC (31110103909, 30901041, 31001016 and 31101729), the State Key Laboratory of Food Science and Technology, the Nanchang University project (SKLF-TS-201108, SKLF-KF201005 and SKLF-KF-201216) and Hunan Provincial Science and Technology Department (2011NK2011 and 2012NK4048). Y. Y. was in charge of the whole trial. W. R. conducted the experiment and wrote the paper. Y. L., G. L., X. Y. and W. L. helped W. R. with the analysis of the data. H. S. helped Y. Y. with the design and review of the whole experimental design. The authors declare that they have no conflicts of interest.

\section{References}

1. Ignjatovic J (1995) Circoviridae: new viruses of pigs, parrots and chickens. Aust Vet J 72, 40.

2. Crawford GR (1994) Circoviridae: new viruses of pigs, parrots and chickens. Aust Vet J 71, 351.

3. Studdert MJ (1993) Circoviridae: new viruses of pigs, parrots and chickens. Aust Vet J 70, 121-122.

4. Allan GM, McNeilly F, Kennedy S, et al. (1998) Isolation of porcine circovirus-like viruses from pigs with a wasting disease in the USA and Europe. $J$ Vet Diagn Invest 10, 3-10.

5. Ellis J, Hassard L, Clark E, et al. (1998) Isolation of circovirus from lesions of pigs with postweaning multisystemic wasting syndrome. Can Vet J 39, 44-51.

6. Segales J, Allan GM \& Domingo M (2005) Porcine circovirus diseases. Anim Health Res Rev 6, 119-142.

7. Opriessnig T, Meng XJ \& Halbur PG (2007) Porcine circovirus type 2 associated disease: update on current terminology, clinical manifestations, pathogenesis, diagnosis, and intervention strategies. J Vet Diagn Invest 19, 591-615.

8. Segales J, Rosell C \& Domingo M (2004) Pathological findings associated with naturally acquired porcine circovirus type 2 associated disease. Vet Microbiol 98, 137-149.

9. Fort M, Fernandes LT, Nofrarias M, et al. (2009) Development of cell-mediated immunity to porcine circovirus type 2 (PCV2) in caesarean-derived, colostrum-deprived piglets. Vet Immunol Immunopathol 129, 101-107.

10. Cao Y, Feng Z, Hoos A, et al. (1998) Glutamine enhances gut glutathione production. JPEN J Parenter Enteral Nutr 22, $224-227$.

11. Neu J, Shenoy V \& Chakrabarti R (1996) Glutamine nutrition and metabolism: where do we go from here? FASEB J 10, 829-837.
12. Tapiero H, Mathe G, Couvreur P, et al. (2002) II. Glutamine and glutamate. Biomed Pharmacother 56, 446-457.

13. Wu GY, Field CJ \& Marliss EB (1991) Glutamine and glucose metabolism in rat splenocytes and mesenteric lymph node lymphocytes. Am J Physiol 260, E141-E147.

14. De-Souza DA \& Greene LJ (1998) Pharmacological nutrition after burn injury. J Nutr 128, 797-803.

15. Wang JJ, Chen LX, Li P, et al. (2008) Gene expression is altered in piglet small intestine by weaning and dietary glutamine supplementation. J Nutr 138, 1025-1032.

16. Li P, Yin YL, Li D, et al. (2007) Amino acids and immune function. Br J Nutr 98, 237-252.

17. Kim SW, Mateo RD, Yin YL, et al. (2007) Functional amino acids and fatty acids for enhancing production performance of sows and piglets. Asian-Aust J Anim Sci 20, 295-306.

18. Wu GY, Bazer FW, Davis TA, et al. (2007) Important roles for the arginine family of amino acids in swine nutrition and production. Livest Sci 112, 8-22.

19. Blachier F, Yin YL, Wu GY (2013). Nutritional and Physiological Functions of Amino Acids in Pigs. Vienna: Springer.

20. Newsholme P (2001) Why is L-glutamine metabolism important to cells of the immune system in health, postinjury, surgery or infection? J Nutr 131, 2515S-2522S (discussion 2523S-2524S).

21. Li X, Hua X, Yang K, et al. (2011) Effects of rice dreg protein and its hydrolysate on growth performance and small intestine morphology of early-weaned rats. J Sci Food Agric 91, 687-693.

22. He QH, Tang HR, Ren PP, et al. (2011) Dietary supplementation with L-arginine partially counteracts serum metabonome induced by weaning stress in piglets. J Proteome Res 10, 5214-5221.

23. Zhang J, Yin YL, He GH, et al. (2012) Effects of MSG supplementation on free amino acids in plasma of growing-finishing pigs. J Food Agric Environ 10, 600-605.

24. Yin FG, Zhang ZZ, Huang J, et al. (2010) Digestion rate of dietary starch affects systemic circulation of amino acids in weaned pigs. Br J Nutr 103, 1404-1412.

25. Wen L, He K, Yang H, et al. (2008) Complete nucleotide sequence of a novel porcine circovirus-like agent and its infectivity in vitro. Sci China C Life Sci 51, 453-458.

26. Yu J, Yin P, Yin J, et al. (2010) Involvement of ERK1/2 signalling and growth related molecules' expression in response to heat stress induced damage in rat jejunum and IEC cells. Int J Hyperthermia 26, 538-555.

27. Kong XF, Zhang YZ, Yin YL, et al. (2009) Chinese yam polysaccharide enhances growth performance and cellular immune response in weanling rats. J Sci Food Agr 89, 2039-2044.

28. Ren WK, Zou L, Li N, et al. (2013) Dietary arginine supplementation enhances immune responses to inactivated Pasteurella multocida vaccination in mice. Br J Nutr 109, 867-872.

29. Wang SP, Yang L, Tang X, et al. (2011) Dietary supplementation with high-dose Bacillus subtilis or Lactobacillus reuteri modulates cellular and humoral immunities and improves performance in weaned piglets. I Food Agr Environ 9, 181-187.

30. Yang HS, Li FN, Kong XF, et al. (2012) Molecular cloning, tissue distribution and ontogenetic expression of Xiang pig Chemerin and its involvement in regulating energy metabolism through Akt and ERK1/2 signaling pathways. Mol Biol Rep 39, 1887-1894.

31. Wang WC, Sh CY, Zhang J, et al. (2009) Molecular cloning, distribution and ontogenetic expression of the oligopeptide 
transporter PepT1 mRNA in Tibetan suckling piglets. Amino Acids 37, 593-601.

32. Yin YL, Huang RL, Zhong HY, et al. (1991) Influence of different cannulation techniques on the pre-cecal digestibility of protein, amino acids and cell wall constituents from diets, containing different protein meal, in pigs. Animal Feed Sci Technol 35, 271-281.

33. Ren W, Yin Y, Liu G, et al. (2012) Effect of dietary arginine supplementation on reproductive performance of mice with porcine circovirus type 2 infection. Amino Acids 42, 2089-2094.

34. Tan BE, Li XG, Kong XF, et al. (2009) Dietary l-arginine supplementation enhances the immune status in early-weaned piglets. Amino Acids 37, 323-331.

35. Kennedy S, Moffett D, McNeilly F, et al. (2000) Reproduction of lesions of postweaning multisystemic wasting syndrome by infection of conventional pigs with porcine circovirus type 2 alone or in combination with porcine parvovirus. J Comp Pathol 122, 9-24.

36. Yu S, Opriessnig T, Kitikoon P, et al. (2007) Porcine circovirus type 2 (PCV2) distribution and replication in tissues and immune cells in early infected pigs. Vet Immunol Immunopathol 115, 261-272.

37. Zoja C, Wang JM, Bettoni S, et al. (1991) Interleukin-1 beta and tumor necrosis factor-alpha induce gene expression and production of leukocyte chemotactic factors, colony-stimulating factors, and interleukin- 6 in human mesangial cells. Am J Pathol 138, 991-1003.

38. Vincent IE, Carrasco CP, Guzylack-Piriou L, et al. (2005) Subset-dependent modulation of dendritic cell activity by circovirus type 2. Immunology 115, 388-398.

39. Vincent IE, Balmelli C, Meehan B, et al. (2007) Silencing of natural interferon producing cell activation by porcine circovirus type 2 DNA. Immunology 120, 47-56.

40. Crisci E, Ballester M, Dominguez J, et al. (2010) Increased numbers of myeloid and lymphoid IL-10 producing cells in spleen of pigs with naturally occurring postweaning multisystemic wasting syndrome. Vet Immunol Immunopathol 136, 305-310.

41. Keene JA \& Forman J (1982) Helper activity is required for the in vivo generation of cytotoxic $\mathrm{T}$ lymphocytes. $J$ Exp Med 155, 768-782

42. Morgan DA, Ruscetti FW \& Gallo R (1976) Selective in vitro growth of T lymphocytes from normal human bone marrows. Science 193, 1007-1008.

43. Smith KA (1988) Interleukin-2: inception, impact, and implications. Science 240, 1169-1176.

44. Flexner C, Hugin A \& Moss B (1987) Prevention of vaccinia virus infection in immunodeficient mice by vector-directed IL-2 expression. Nature 330, 259-262.

45. Allen EM, Weir JP, Martin S, et al. (1990) Role of coexpression of IL-2 and herpes simplex virus proteins in recombinant vaccinia virus vectors on levels of induced immunity. Viral Immunol 3, 207-215.

46. Biffl WL, Moore EE, Moore FA, et al. (1996) Interleukin-6 in the injured patient. Marker of injury or mediator of inflammation? Ann Surg 224, 647-664.

47. Naugler WE \& Karin M (2008) The wolf in sheep's clothing: the role of interleukin- 6 in immunity, inflammation and cancer. Trends Mol Med 14, 109-119.

48. Trinchieri G (2007) Interleukin-10 production by effector $\mathrm{T}$ cells: Th1 cells show self control. J Exp Med 204, 239-243.
49. O'Garra A, Barrat FJ, Castro AG, et al. (2008) Strategies for use of IL-10 or its antagonists in human disease. Immunol Rev 223, 114-131.

50. Darwich L', Segales J, Resendes A, et al. (2008) Transient correlation between viremia levels and IL-10 expression in pigs subclinically infected with porcine circovirus type 2 (PCV2). Res Vet Sci 84, 194-198.

51. Farrar MA \& Schreiber RD (1993) The molecular cell biology of interferon-gamma and its receptor. Annu Rev Immunol 11, 571-611.

52. Conner EM \& Grisham MB (1996) Inflammation, free radicals, and antioxidants. Nutrition 12, 274-277.

53. Lora J, Alonso FJ, Segura JA, et al. (2004) Antisense glutaminase inhibition decreases glutathione antioxidant capacity and increases apoptosis in Ehrlich ascitic tumour cells. Eur J Biochem 271, 4298-4306.

54. Wu G, Fang YZ, Yang S, et al. (2004) Glutathione metabolism and its implications for health. J Nutr 134, 489-492.

55. Gras G, Porcheray F, Samah B, et al. (2006) The glutamateglutamine cycle as an inducible, protective face of macrophage activation. J Leukoc Biol 80, 1067-1075.

56. Spittler A, Winkler S, Gotzinger P, et al. (1995) Influence of glutamine on the phenotype and function of human monocytes. Blood 86, 1564-1569.

57. Wells S, Kew S, Yaqoob P, et al. (1999) Dietary glutamine enhances cytokine production by murine macrophages. Nutrition 15, 881-884.

58. Ren W, Luo W, Wu M, et al. (2011) Dietary L-glutamine supplementation improves pregnancy outcome in mice infected with type-2 porcine circovirus. Amino Acids (Epublication ahead of print version 16 November 2011).

59. Kiupel M, Stevenson GW, Choi J, et al. (2001) Viral replication and lesions in BALB/c mice experimentally inoculated with porcine circovirus isolated from a pig with postweaning multisystemic wasting disease. Vet Pathol 38, 74-82.

60. Kiupel M, Stevenson GW, Galbreath EJ, et al. (2005) Porcine circovirus type 2 (PCV2) causes apoptosis in experimentally inoculated BALB/c mice. BMC Vet Res $\mathbf{1}, 7$.

61. Li J, Yuan X, Zhang C, et al. (2010) A mouse model to study infection against porcine circovirus type 2: viral distribution and lesions in mouse. Virol J 7, 158.

62. Quintana J, Balasch M, Segales J, et al. (2002) Experimental inoculation of porcine circoviruses type 1 (PCV1) and type 2 (PCV2) in rabbits and mice. Vet Res 33, 229-237.

63. Opriessnig T, Patterson AR, Jones DE, et al. (2009) Limited susceptibility of three different mouse (Mus musculus) lines to porcine circovirus-2 infection and associated lesions. Can J Vet Res 73, 81-86.

64. Bolin SR, Stoffregen WC, Nayar GP, et al. (2001) Postweaning multisystemic wasting syndrome induced after experimental inoculation of cesarean-derived, colostrum-deprived piglets with type 2 porcine circovirus. J Vet Diagn Invest $\mathbf{1 3}$, 185-194.

65. Lewis B \& Langkamp-Henken B (2000) Arginine enhances in vivo immune responses in young, adult and aged mice. J Nutr 130, 1827-1830.

66. Wu G (2009) Amino acids: metabolism, functions, and nutrition. Amino Acids 37, 1-17.

67. Kudsk KA (2006) Immunonutrition in surgery and critical care. Annu Rev Nutr 26, 463-479. 